\title{
Applying duoethnography to position researcher identity in management research
}

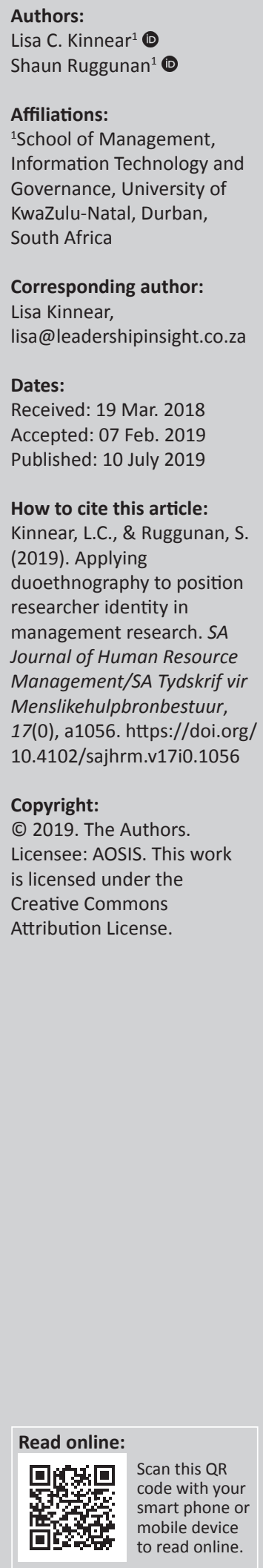

Orientation: South African management studies do not have a strong tradition of qualitative, critical and reflexive research. We explore how this may occur through a reflection on researcher identity.

Research purpose: To critically reflect on the focussed dialogue and reflection between the authors and to demonstrate how duoethnography can challenge management scholars to become more reflective of their scholarship.

Motivation for the study: To show how duoethnography can be applied in management studies scholarship as a methodological approach.

Research approach/design and method: A duoethnographic approach is used. This is a collaborative form of autoethnography between two researchers. The researchers themselves become the participants of the study. The dialogue between the researchers is reflective of shared, sometimes conflictual experiences on a focussed topic or research question. We reflect on the ways our dialogues influence Lisa's reflection of her own identity when conducting qualitative doctoral research with a feminist lens. Her identity is also influenced through some of the narrative texts of the women she interviewed during her fieldwork.

Main findings: The account concludes that duoethnography challenges the positivist position that researcher identity is objective from the participants we research. We show that gender, race and epistemic assumptions are not simply quantitative variables.

Practical/managerial implications: The practical implication of the study is to encourage management scholars to engage in duoethnographic collaborations as a means to facilitate critical reflection on current and past work.

Contribution/value-add: The study provides an original duoethnographic account that is an uncommon reflective practice in a management research context.

Keywords: autoethnography; critical management studies; critical reflexivity; duoethnography; feminist epistemology; feminist management scholarship; intersectionality; qualitative research; researcher positioning; whiteness.

\section{Introduction}

In this article, the authors seek to show how duoethnography, as a form of reflective conversation and collaboration between researchers about the social phenomena they research, can generate new insights for management scholars. These new meanings can be about researcher identity as well as the empirical work in which they engage. Norris and Sawyer (2012) show how co-reflectivity through dialogical methods such as duoethnography can influence research identity and change their perceptions of the research they engage in. This form of inquiry means that researchers (in this case, Lisa and Shaun) become the participants in the study. We use our personal narratives about our researcher identity as a lens to reflect on larger themes in management scholarship (Lisa's [postdoctoral candidate, white female] work on women as leaders and Shaun [Associate Professor, Indian male] work on critical management studies [CMS]). This form of critical conversation causes us to reflect on the limits of our own academic training in management studies.

\section{Shaun stated:}

‘Despite branding myself as a progressive management studies scholar, I have nevertheless been blind to the way my identity as a man has shaped my empirical work. Yes, I have written about gender, but after discussing and being challenged by Lisa, I have not done this in an emancipatory, or even a feminist way.' 
Lisa said:

'Shaun also asked how race intersected with gender. I had to think deeply on what it means to be a white female researcher using a feminist lens. Critical management studies (CMS) for example pays considerable attention to racial identity and intersectionality. But based on our dialectical exchange, have I unwittingly erased race from my feminist lens?'

Breault (2016) demonstrates how traditional academic training in methodology can devalue the critical conversation and co-reflection of researchers by dismissing it as unscientific. It is by recognising the limitations in our own training that we are able to cross boundaries of what is methodologically possible beyond the traditional scientific method that is the mainstay of management studies (Alvesson \& Ashcraft, 2009; Beltramini, 2018).

Management scholarship globally has developed niche areas of expertise in narrative forms of inquiry. Dedicated journals on ethnography and qualitative methods in management studies show that there is a small but vibrant community of scholars that engage in this approach (Doloriert \& Sambrook, 2012). The postmodern influence of critical theory on management studies also shows a preference of critical management scholars to use narrative forms of inquiry (Alvesson, Bridgman, \& Willmott, 2011). However, duoethnography as a specific approach is less popular than organisational ethnography and autoethnography (Alvesson et al., 2011). The approach seems to be especially favoured by management scholars engaging in interdisciplinary work or collaborating with scholars in disciplines outside of management studies (Doloriert \& Sambrook, 2012; Norris \& Sawyer, 2016).

Nationally, the method is one favoured by those in the education and psychology fields (Van Schalkwyk \& McMillan, 2016). Although work by Meier and Geldenhuys (2017) shows that industrial psychologists also value this approach. Qualitative approaches such as O'Neil and Koekemoer (2016) are underutilised in South African management studies. The low use of qualitative studies in management scholarship in South Africa favours traditional qualitative approaches as opposed to narrative forms as is suggested by their work. This work expands the range of options available to qualitative researchers in the field.

This article is presented in layers. These layers are akin to a rainbow cake. Each layer makes a contribution to forming a unified whole. We begin with an overview of the research design and research approach. Thereafter, we navigate through the dialogues and discussion that emerged through our critical reflection. Finally, we conclude with how we think our work can contribute to doing duoethnography in management studies. The article is guided by the following research question:

'How does duoethnography enable or facilitate critical reflection and insight into the identity of management scholars?'

\section{Research design and approach Overview of duoethnography}

Duoethnography provides a creative postmodern approach to qualitative research. It is a form of collaborative autoethnography (Ellis, Adams, \& Bochner, 2011). Duoethnography is rooted in the philosophical and theoretical foundations of autoethnography (Fitzpatrick \& Farquhar, 2018; Norris, 2008). Autoethnography is a deeply personalised account of the researcher's experience to 'extend understanding about societal phenomena' (Anderson, 2006; Wall, 2006, p. 1). It is a way of accessing personal experience to extend the sociological imagination about social issues in the researcher's discipline (Smith, 2005). Autoethnography relies on the narrative of the self and is a well-regarded form of qualitative inquiry in social science disciplines such as education and psychology. Duoethnography, while borrowing from the same interpretivist and postmodern philosophical underpinnings as autoethnography, is less well established. The method was first proposed by Sawyer and Norris (2005). They sought to shift from the meta self-narrative of autoethnography to a method where our stories could be explored in dialogue or what they term 'dialogic tension' (Sawyer \& Norris, 2015). In 2015, Sawyer and Norris confirmed that despite its youthfulness and novelty, duoethnography has enjoyed a decade of empirical and theoretical growth as a methodological approach.

The duoethnographic approach is a form of self-narrative that is critically reflective and dialogic between the participants. It is therefore an approach situated within the larger qualitative category of inquiry-based research that 'poses questions and challenges dominant discourses' during its exploration of the lived experiences of its participants (Fitzpatrick \& Farquhar, 2018, p. 238). Despite it being an emerging form of narrative inquiry, duoethnography is becoming entrenched within the literature as a valued way of engaging in critical reflexivity between two or more participants. Duoethnography finds its roots at the nexus between various forms of narrative approaches (narrative inquiry, narrative identity, currere) and critical theory (Hooks, 1994).

\section{Trustworthy duoethnography}

Norris and Sawyer (2012) and more recently Breault (2016) have been made to delineate more clearly the criteria for what makes a 'good' and trustworthy duoethnography. Breault (2016) provides a list of 23 criteria to consider when evaluating duoethnography. The quality and trustworthiness of the duoethnography is revealed through the transparency of the writing, not any claims to objectivity and truth. We have tried within the limits of an article to show as transparently as possible our shared vulnerabilities. We do not offer conclusive objective findings, but rather suggestions for further scholarly exploration.

There is an acknowledgement that there is no single way of doing duoethnography provided core criteria are met (Norris \& Sawyer, 2012). 
These include:

- Polyvocal and dialogic: There must be a focussed dialogic exploration between participants. The focus is important because it is easy for participants to engage in unfocussed 'chats' like two friends at a coffee shop. We focussed our dialogue on a central reflective question:

- How does racial, gendered and epistemic identity shape the research experience?

- Comparing the life experiences of two or more participants (in our case the authors of this article) to reveal points of complexity in their identity, also known as currere (life curriculum). The comparison must reveal points of difference and similarity in how participants' social and cultural milieus influence their identities. We focussed our juxtaposition on our gendered, cultural, experiential, epistemological, racial, organisational and work identities. This involved what Van Schalkwyk and McMillian (2016, p. 212) refer to as an 'interrogation of each other's position while foregrounding one's own'.

- Disruption of meta-narratives: The dialogic component of duoethnography is to assist in disrupting the mainstream or meta-narratives that can emerge in writing alone. Duoethnography must show its intersections with critical theory. It must as Breault (2016, p. 10) argues, 'disturb the waters'. As scholars, we found ourselves in the thick of profound and complex change at the University of KwaZulu-Natal (UKZN) and higher education in South Africa generally. Yet, management scholars and scholarship in South Africa did not seem to be engaging substantively in what it may mean to disrupt the mainstream narrative of management studies (Goldman, 2016; Nkomo, 2018). What would such an engagement mean for scholarly identity? Our dialogic experience then is a reflection on how mainstream management studies could intersect with critical theory.

\section{Participants and the study site}

Given that duoethnography makes the researchers the study participants and 'study site', some insight into the researcher identities is needed.

Shaun has been working as an academician in management studies since 2011. Currently, he is an associate professor of human resources management (HRM) at UKZN. Prior to 2011, he worked as an academician in the programme for industrial, organisational and labour studies (IOLS). Industrial, organisational and labour study is a sociology and labour studies discipline. He struggled with the disciplinary shift from a sociologically and qualitatively rooted discipline (IOLS) to HRM. Human resources management is rooted in psychology and has a quantitative bias in its methodological approach (Bratton \& Gold, 2015).

The struggle consisted of grappling with the epistemic differences both methodologically and disciplinarily. For example, IOLS at UKZN produced almost exclusively qualitative work that focussed on worker empowerment and was critical of managerial control. Human resources management, on the other hand, at UKZN was quantitatively based and focussed on how to make managerial control more effective. The tensions informed the struggle. The tension forced a critical reflection on what the intellectual purpose and project is of management studies in a developing state context. Shaun also identifies primarily as a qualitative researcher. His identity as a male scholar and person of colour (Indian South African) is important in the context of this duoethnography.

Lisa was a postdoctoral candidate supervised by Shaun from 2015 to 2017. She is an experienced leadership coach and runs her own leadership consultancy. She has an academic background in the humanities, a master's degree in HRM from Wits Business School and completed her PhD in HRM at UKZN. Lisa identifies as a feminist and qualitative researcher in HRM. Subsequent to her postdoctoral candidature, she continues with her consultancy work. Lisa is classified as an English-speaking South African white female. Racial and gendered identities were important points of engagement for both researchers.

\section{Data collection}

Two forms of duoethnography are common in the literature. First is a 'storytelling' approach where the narratives of the authors are given and discussed in tension with each other. There is no separate results and discussion section in writing up the narrative. Rigour occurs through the various iterations of the dual narratives. The second type is the review of memorabilia such as scrapbooks and photo albums that act as memory prompts for the researchers (Norris, 2008, p. 236). It is the former approach that we have adopted here.

Our duoethnography developed organically as we worked on other projects from 2015 to 2017. Our main purpose during this period was to develop HRM papers for publication. However, our professional conversations became increasingly centred around researcher and discipline identity in the context of the rapidly changing South African higher education context. We bracketed these conversations and notes because they were not central to our purpose of producing empirical papers for publication. At the end of 2017, we realised that we had curated a number of dialogical experiences, which had become focussed on the identity of the management studies scholar and purpose of the discipline. Guided by the work of Norris and Sawyer (2012), we decided to formalise our duoethnographic study. This meant verifying our recollections, disagreements and notes that were taken at meetings. We share our experience of this process by reflecting on a key reflective question:

\section{How does racial, gendered and epistemic identity shape the research experience?}

As long as the data related to the reflective questions, we engaged with it and curated it. The data or our 'narratives' consisted of notes, email threads and self-reflective narratives that we had produced over a 2-year period. 
The collection was fluid as is often the case in qualitative research (Norris \& Sawyer, 2012). Further, the way in which data are collected and recorded is not prescriptive (Norris \& Sawyer, 2012, p. 139).

\section{Data analysis}

Data analysis is not necessarily a separate process from data collection in qualitative research (Chang, 2007). However, it is found that having some sequential structure assisted in organising the themes of the study. Firstly, we curated all our texts (emails and notes) that we felt fell within the focus of the reflective question. We then independently generated our own self-reflections in written form based on this curated material as well as our experience as researchers over the 2-year time period (2015-2017). Thirdly, we then exchanged our narratives, and met four times in 2018 to discuss the narratives. A key purpose of these meetings was to organise the narratives thematically. The themes were then labelled as Dialogue 1, Dialogue 2 and Dialogue 3.

\section{Limitations of duoethnography}

Methodologically, the value of our duoethnographic approach avoids the potential self-indulgence of autoethnography (the fetishisation of self). This means that the researcher can be so subjective in their account that there is no room for an account or validity beyond the self. In its extreme form, only the self has access to certain 'truths' about the social world (Schultz, 2016). Similarly, duoethnography avoids the potential exploitation of ethnographic approaches (Schultz, 2016). Ethnographic approaches sometimes situate the researcher as an expert who accesses the worlds of nonexperts. In such cases, the position and identity of the expert may lead to condescending views or interpretations of behaviours by non-expert participants. The colonial roots of ethnography in anthropology, for example, still manifest themselves along the only valid truth being that of the expert entering the field (Schultz, 2016). This is not to say that duoethnography itself cannot fall prey to the pitfalls of selfcenteredness or power differentials of participants, but that the focussed dialogue provides a form of a 'check and balance' (Guyotte \& Sochacka, 2016).

\section{Framing our duoethnographic dialogue}

Both participants in this study wanted to engage in reflections of their roles as knowledge producers. Critical theory that encourages reflection and destabilises what we think we know was an appropriate approach to root our reflections. Critical theory has its roots in the sociology and philosophy of the 1930s. Attributed to the Frankfurt School, it is associated with the work of Horkeheimer (1947), Marx (1850-1867), Freud (1905-1940) and Gramsci (1916) among other social scientists who wanted to provide a critique that was taken for granted by social and cultural assumptions of the world.

Critical theory has informed a range of social science disciplines from psychology to sociology and management studies (Alvesson et al., 2011). At its core are two assumptions (Alvesson et al., 2011):

- The researcher has to be critically reflective of her or his own role in knowledge production.

- The purpose of scholarship is to denaturalise assumptions taken for granted and reified by positivist assumptions of the social world.

When applied to management studies, a third premise of a critical approach is:

- Questioning the performativity assumption at the core of management studies. In other words, questioning the idea that increasing performativity (production, outputs and profits) should be the main purpose of management studies (Fleming \& Banerjee, 2015).

Collectively, these three criteria are the core assumptions of a CMS approach. We were particularly attuned to focusing on the first two assumptions that encouraged critical reflexivity for the purposes of this article.

Shaun had some experience with CMS professional associations and had published exploratory work on CMS. Lisa, with her doctoral work on feminism and leadership, did not immediately see her work on feminism as part of the CMS oeuvre. These two positions of the participants produced a productive tension for the dialogue required for duoethnography.

\section{Ethical considerations}

All principles of informed consent were followed. Apart from the identities of the authors, all principles of anonymity and confidentiality were abided by to protect participant identities.

\section{Dialogues and discussion}

The themes organised will be presented according to the dialogues we had.

\section{Dialogue 1: Vulnerability through critical reflection}

For Shaun, the connections between feminist management scholarship and CMS were more visible. However, he did feel out of his depth with current scholarship on feminism and had to read and discuss more about feminist approaches to management with Lisa.

\section{Shaun recollects:}

'It was interesting that Lisa was reading my work on CMS and I was reading her work on feminist management scholarship (FMS). I was so excited because my own thinking and writing on CMS did not acknowledge in any serious way the role of feminism as emancipatory to management scholarship. Perhaps my own positionality as male and implicitly viewing male as universal created this blind spot? I considered myself a feminist, but upon reflection, I found my own empirical work did not 
engage with gender in a serious or reflective way. Instead, I tended to privilege race as identity rather than gender in my work. This made me feel vulnerable as I reflected on what this means for me as a management scholar that actually thinks he is progressive.'

\section{For Lisa:}

'While I resonated with the CMS literature and acquired more insight into Shaun's views by reading his writing on it in a South African context, it made me feel quite vulnerable about the firstly tentative and then seemingly naïve positioning of my work as a feminist. I felt that there was so much more I needed to consider in challenging the management studies agenda. I also felt I still had to clarify my position on feminist management scholarship and this was not an easy thing to do. I remember Shaun asking me whether we have not possibly moved beyond a feminist agenda into a post-feminist space and I wasn't sure how to respond. Shaun's challenge to me made me reflect on my inability to clearly articulate what a feminist perspective in research is. Feminist scholarship itself is so divided that despite having immersed myself in the literature for my PhD studies, I still felt quite confused at times. The discussions and debates with Shaun forced me to reflect on my own position and assumptions about feminist research.'

Shaun and Lisa had a robust discussion and some disagreement on the privileging of qualitative work in FMS. Does this mean that quantitative research cannot be critical or feminist? Is all qualitative research critical? We agreed that these questions need to be included in mainstream management scholarship in South Africa. One path of achieving this inclusivity is to engage in critical reflexivity. Unfortunately, this type of reflection is not present or possible in the majority of quantitative scholarship in management studies (Bratton \& Gold, 2015). Positivism situates the researcher as an 'objective' from the study and its participants or 'subjects'. Critical reflexivity is one of the three tenets of CMSs (Alvesson et al., 2011) that we argue provide one possible pathway to reimagine the intellectual project of management studies.

Asking these questions of each other and ourselves often made both of us feel very vulnerable in our expert roles as academicians and practitioners, but was necessary as a means of making us reflect on our own and each other's professional identities.

\section{Dialogue 2: Qualitative researcher identity}

Lisa and Shaun reflected broadly on the marginalisation of qualitative research in management studies. Empirical work supported our suspicion of marginalisation. For example, O'Neil and Koekemoer's (2016) work found a lack of development of qualitative research methods in South African organisational or industrial psychology and HRM. Indeed, they argue that qualitative research is often 'undervalued and misunderstood' in these disciplines. In a study conducted at UKZN into the bibliometric features and trends in the South African Human Resource journals between 2005 and 2015, Ruggunan and Sooryamoorthy (2015) found that the knowledge produced remains overwhelmingly positivist and quantitative. The studies were largely replications of previous studies (theory testing) rather than theory building. Conceptual, theoretical and new methodological (especially qualitative) interventions were limited. Work by Pietersen (2018) had similar findings.

Our dual reflection guides us to believe that positivism in and of itself is not the challenge. Positivist work can be deeply critical. At the same time, just because work is qualitative does not automatically make it critical work or reflective work. Rather at issue is the normative position it has assumed in management research in South African institutions, which not only influences how research is being conducted, but also the nature of the questions being asked (Dunbar \& Rottner, 2014). For example, philosophical and epistemological justifications are rarely asked of quantitative studies but are demanded of qualitative projects. Lisa's experience of this as part of the process of getting her doctoral proposal presentation accepted by the doctoral committee demonstrates the claim that qualitative methods are often undervalued, misunderstood or regarded as less rigorous and scientific than quantitative methods ( $\mathrm{O}^{\prime}$ Neil \& Koekemoer, 2016). Shaun also recollects his own challenges as a supervisor of qualitative projects, when research committees apply quantitative criteria to assess qualitative proposals.

While qualitative research is limited in mainstream management studies in South Africa (Goldman, 2016), CMS favours this methodological approach because of its promotion of reflexive inquiry. Hibbert and Cunliffe (2015) draw a distinction between critical reflexivity and selfreflexivity where being self-reflexive questions one's own way of being, relating and acting and where being critically reflexive involves questioning assumptions of underlying social and organisational practices. They argue that these two processes go hand in hand, but that both compel the researcher to reveal her or his position and philosophies as integral to the research findings.

Shaun and Lisa had much engagement on why this reflection or positionality is always expected of qualitative researchers and not quantitative researchers. Shaun and Lisa then articulated their own positionality and the potential blind spots, in which they may reveal more about themselves and their work.

Shaun recollects:

'My assumption that being a CMS scholar made me automatically a feminist scholar may not actually be true. Without this engagement from Lisa, I most likely would not have become aware of this invisibility in my work.'

Lisa reflects:

'Shaun really pushed me about what a feminist lens is. I think explaining it to a non feminist researcher and a male forced me to reflect more carefully on this. The feminist lens which I applied to my $\mathrm{PhD}$ research was a position I had to make explicit. This was challenging at times, as it meant attaching a fixed label to the research and my researcher identity which did not seem to 
accommodate the notion that identity work involves the dynamic between internal processes and external prescriptions within changing contexts. In reflecting on this challenge, I have been able to deepen my understanding of feminist epistemologies and the approach I adopted for my research.'

\section{Dialogue 3: Identity, reflexivity and reinterpreting fieldwork}

Shaun and Lisa decided that one way to show critical reflection in action would be to engage in a reframing of Lisa's doctoral work through critical reflexivity. Shaun and Lisa both read the work and identified points of intersection and tension that exist between CMS, FMS and researcher identity.

What follows is Lisa's iterative account of her reflection as a qualitative and feminist researcher. The narrative is an outcome of their collaborative encounter. Based on Shaun and Lisa's dialogues, Lisa's narrative reflects on the ways in which her feminist approach is simultaneously reflective of both feminist and CMS principles.

Shaun encouraged me to revisit my work to examine how it resonates with a CMS approach. At year 2 into our dialogue, we felt comfortable enough to disagree or 'push' each other on points that we felt would further the significance of our work. We agreed that I would reflect deeper on my racial identity. We accept that race is a social construct but acknowledge that it has very material consequences especially in the South African context. Shaun felt that this reflection on the material influence of race did not emerge strongly enough in my original work. Shaun was quite transparent in expressing his own vulnerabilities about the material ways in which his 'maleness' made him less aware of feminist issues. I was initially very uncomfortable with the suggestion that my 'whiteness' needs to be reflected on more deeply as part of my researcher identity.

Part of our dialogue when we met after receiving reviewer comments was around sharing these vulnerabilities. How do we share our vulnerabilities with a wider audience? How do we do this difficult task of reflecting the transformation of both our researcher identities? We then realised that the original framing of this work as an autoethnography was perhaps not accurate; that the exploration of identity and reflection was the outcome of a collaboration, namely a duoethnography. With so much of the culture of academic scholarship being insular and often done with students, as professional researchers, we are not accustomed to dialogical learning and conversation with each other. Hence, when professional researchers do converse, it usually centres on the empirical findings rather than a questioning of what their identities bring or do not bring to the research. Certainly, in South African management studies, reflecting on research identity seems to be an anathema.

As a woman working as an organisational development practitioner in the South African corporate world and a researcher in management studies at UKZN, my $\mathrm{PhD}$ research was motivated by my own tussles with power and privilege in dealing with the corporate hierarchies of patriarchal institutions. The aim of my $\mathrm{PhD}$ study was to deconstruct women leaders' models of power which have been constructed within a patriarchal social context and to identify emerging models that may be less accessible or easily articulated.

As a white woman, my experiences of power and white privilege growing up under apartheid influenced the way in which I related both to those I was interviewing and the way in which I was reading their texts. Using critical reflection through the research process was key to understanding that as a researcher, I am not an independent entity in the research (Ponterotto, 2013). Any form of qualitative research requires researchers to be aware of how their race, class, gender and status inform their research agenda and theoretical frameworks.

Initially, I hesitated to position my $\mathrm{PhD}$ study as feminist perse, but in engaging with the literature and the methodology during my PhD journey, it became clearer to me that this was, in fact, a feminist study because the focus was on women and power which is at the heart of feminist debates (Kinnear \& Ortlepp, 2016). In addition, the aim of my research was to contribute to the transformation of gender relations in South African business organisations by raising consciousness of the impact of patriarchal relationships on how women lead. I believe I was conflicted over my own feminist identity, given that the study was being conducted within a management context where the notion of feminism is often misunderstood and alienating for my female and male colleagues. In addition, the notion of feminism in the South African context is further complicated by my privilege as a white South African. My experience of what appeared to be labelled as 'feminist' behaviour within a corporate context I found unnatural and often complicit with patriarchal practices of dominance.

To have a feminist lens in a management research study considered valid by UKZN was achieved through collaboration with academicians from social science and psychology backgrounds who understood both the purpose of the study and the methodologies supporting it. This was necessary because expertise in CMS and feminist epistemology were not available in the school of management at UKZN at the time. The rewarding consequence of this process was the collaborative and interdisciplinary nature of the research which provided opportunity for greater reflexivity of the researcher and consequently the discipline itself. It also provided the opportunity to explore women's emerging models of power and reinvent theory outside the constraints of conventional management theories.

The focus of my research on the identity constructions of South African women business leaders around power and their leadership role highlighted some of the tensions that exist, both conscious and less conscious, in attempting to 
operate with authenticity in a patriarchal world. According to Letherby (2003), a focus on the relationship between the self and the other through autobiographical narration encourages reflection on power relationships. The link between language, power, identity and feminism was a significant consideration in choosing the method of discourse analysis of narratives in my $\mathrm{PhD}$ research (Kinnear \& Ortlepp, 2016). The autobiographic narratives of women were considered a valid vehicle for understanding how women construct their reality and their power within it. Feminist researchers such as Hooks (2010) argue that autobiography is a particularly apt way of telling and claiming ownership of one's life and identity as it enables the author to tell their version of events through uninterrupted means.

I noted the issues of intersectionality of race, gender and class as a limitation in my research, recognising that a researcher with a different background to my own would access a different sample group and provide new insights to the types of questions I was asking. While I highlighted the complexity of these intersectionalities in my PhD thesis, it has been through my subsequent reflections and in the sharing of my research that I have been prompted to review the issue of intersectionality more deeply and critically.

In her reflections on being a feminist academician in South Africa, Gouws (2012) highlights the fact that the intersectionalities of identities, such as race, class and gender, are more pronounced in South Africa than in most other societies. In recounting her experience of feminist teaching at an Afrikaans language medium South African university, Gouws (2012) raises the issue that theories developed need to include both race and gender components to validate their experiences, something that often pits white students against black because their lived experiences are so different.

Despite our varied backgrounds, the fact that all of the interviewees were in senior positions of leadership in large corporations meant that we shared an aspect of privilege as leaders in our respective fields. Nevertheless, an uncomfortable dynamic developed between myself and one of the white interviewees. I felt that she wanted to collude with me when discussing issues of racial power dynamics and protection of privilege. This was evident in her confessional anguish in managing perceptions of racism to prevent limitations to her career advancement, rather than reflection on and development of self-awareness around privilege and race.

This is her response to the open-ended question of how she views power in her leadership role:

'I was wondering if this would come up. When I was there, a senior manager accused me and another manager of a whole lot of things ... one of them being a racist. Lisa, I had about a year to go to partner and I just saw my career go up in flames before me ... it was very traumatic and I honestly thought that my days at the company were numbered ... and in my mind I still think I know what triggered it and what it's taught me is that perceptions are incredibly powerful ... It might be wrong, but if people perceive you as something, they can destroy you.' (Sarah*1, financial director, female)

The concept of white privilege is a strong theme in the political discourse of post-apartheid South Africa today which requires greater scrutiny beyond the contested colloquial rhetoric. Several authors agree that the valuation of white skin colour continues to grant invisible, unfair privileges to white people which is not consciously acknowledged and which continues to perpetuate social inequalities of our apartheid legacy (Le Roux, 2014; Milazzo, 2015; Swartz, Arogundade, \& Davis, 2014). As gatekeepers of privilege, the white minority in South Africa still controls the advancement of women and black women in corporate institutions (Carrim \& Nkomo, 2016).

The fact that black women are more significantly represented in the public sector is evidence of the white monopoly in business, despite Broad-Based Black Economic Empowerment (BBBEE) legislation (Mall, 2015). This has led to the questioning of whether white women should remain beneficiaries of affirmative action policies because of their relative advantage, even though they still suffer from gender discrimination in the workplace (Kinnear \& Ortlepp, 2016).

By taking me into her confidence as a white woman needing to manage perceptions of racism to ensure her career advancement, I felt vulnerable. Was I similarly inauthentic in my response to race? Shaun's challenge to me to reflect more deeply on my 'whiteness' made me realise that despite the fact that I feel reflective around white privilege, I too suffer from not wanting to be perceived in a certain way. This makes me feel self-conscious in my discussions on race and was probably the reason why I failed to engage more deeply with the intersecting effects of race and gender in my $\mathrm{PhD}$ thesis.

Despite this, I was acutely aware that all of the black women I interviewed raised the challenge of dealing with racial and gender stereotypes in their narratives, as in the following example:

'I have always known that in business I have two stripes against me...one female, and two, I am black. While I cannot ignore that, many people would like to wish it away, but it is a reality you know ... But I always say the biggest reality is to sink into your head, to look at yourself, not as a woman, not as a black, then other people won't see you as that ... they will see you as an equal counterpart.' (Siwe*, corporate service director, female)

In this extract, Siwe narrates her power as the deconstruction of internal victimisation and the construction of an external legitimate claim to power (Harvey, 2010). This deconstruction is both conscious and tactical and while it appears to challenge the categorisation of intersectionality, it is based on recognising these social stereotypes and actively performing to counter 1.Asterisk $(*)$ represent pseudonym used for participant. 
these in a professional setting. Later, in her interview, she narrates her reflections on feeling disempowered within the private space of marriage which challenges the ability to sustain this performance of equality and rejection of gender categorisation.

'In African culture you have to be, women have to be seen and not heard ... So often in the first few months my mother in law used to tell me to 'keep quiet' you know ... let my husband feel he is in control, he has made the decision. I must be honest it disoriented my whole thinking, I just felt so disempowered.' (Siwe*, corporate service director, female)

The disempowerment and disorientation that Siwe describes constructs the struggle for congruence between her personal and professional identity. It also raises the contextual nature of power and authority (Fleming \& Spicer, 2014). It supports the view that identity construction is continuously changing across contexts and structures (Carrim \& Nkomo, 2016). For this reason, I wanted the interview process of my research to allow the women to construct their own multiple and emerging identities through their autobiographical narration. What emerged as a common construction of power among all of the women I interviewed was continuous striving for 'congruence' in their multiple identities (Kinnear \& Ortlepp, 2016). This congruence is something I myself am striving for in my research identity and positioning, recognising that qualitative research is far more complex than it appears given the shifts in our 'selves' within multiple contexts.

This prompted my critical reflexivity on two experiences I had while presenting the findings of my $\mathrm{PhD}$ research at two UKZN conferences. The first was a Women in Leadership event hosted by UKZN for university administrative support staff for Women's Day. My presentation was preceded by a woman guest speaker who addressed the group on accurately determining their bra size while promoting her business selling women's underwear. I felt outraged that within a university setting which should be more mindful of issues around gender construction, women were being traditionally reduced to sexual objects. But equally, I felt disempowered and silenced as I continued to uphold my professional identity and delivered my presentation without raising any concerns. I wondered whether a similar event would have been arranged for women academicians and how it would have been received. This also made me reflect on the notion of how feminist issues themselves become privileged in terms of rank and status in society.

The second occasion was a college research day in which I was included in a group of all male researchers whose initial response to my research on women and power in the corporate world was to question me on women's constraints as the bearers of children and the domestic arrangements between women and men. This experience had the alienating effect of demeaning the significance of my research and women in leadership roles in the corporate world in general. I felt attacked and belittled by members of the male audience who chose to focus on my gender identity in relation to domestic stereotypes. Bell and King's (2010) paper on management studies conferences as a site of body pedagogics acknowledges the role of conferences as a means of socialisation into academic cultures and a rite of passage for formulating an academic identity. Ford and Harding (2010) argue that conferences typically perpetuate gender imbalances between male and female professionals because the cultural norms often marginalise women out of the public space into the domestic sphere and subject them to a process of infantilisation. These two experiences left me feeling totally disillusioned with the university context as a space for exploring feminist issues. In my debriefing meeting with Shaun after this event, he encouraged me to incorporate these experiences in my postdoctoral reflections.

My experiences in these forums have highlighted the poorly understood concept and complexity of feminist research and the issues being raised in a management context. It supports the need for research into gender dynamics that seeks to understand rather than predict, ensuring that researchers are not speaking for 'others' through a positivist predictive set of metrics based on constructions of what is 'true' (Davis, 2008). Despite feeling the effects of this, my vulnerability at the second conference was also because of the fact that I was speaking to a predominantly African male audience. Embracing the label 'feminist' within the South African context has the potential of alienating African men because of their solidarity with women in the struggle against apartheid and because of perceptions of feminism as a western import (Gouws, 2012; Miller, 2016).

Some scholars have argued that postmodern theories, such as feminism, have done little to shift material realities in Africa (Nkomo, 2011) and believe that white women academicians can undermine African grassroots women's organisations (Prinsloo, 2016). Miller (2016) in her chapter on the political positionalities of what she terms the 'new African woman' and the older feminist acknowledges that South African feminists struggle with their identity as 'women', alternately resisting and accepting socially prescribed roles that inhibit self-expression. However, she highlights the common experiences of women in a society which resists the integration of women in public spaces, in large and small ways, no matter what their position of power is within that space. The response of the conference audience to my positionality as a researcher resulted in my questioning how positioning and intersectionality can be raised in a public space in a way that promotes transparent and constructive dialogue around issues of race and gender, rather than prejudiced interactions.

While intersectionality was first termed to understand multiple marginalisation (Crenshaw, 1991), the question of focusing on identity categories has come under criticism within the CMS literature as a potential way of perpetuating further division and segregation (Lykke et al., 2014; Ruel, Mills, \& Thomas, 2015). Yet, within the highly racialised context of South Africa's past and present, contextual studies need to take race into account (Carrim \& Nkomo, 2016; Ruggunan, 2016; Zanoni, Janssens, Benschop, \& Nkomo, 2010). The question remains as to how issues of race and 
culture are brought to the fore in a way that eliminates boundaries of categorisation, while acknowledging South Africa's racialised context. Rethinking intersectionality also calls for reassessing the academic spaces where research can be shared in ways that are more conducive to the exchange of ideas and where the fluidity of identity can be experienced as a given, rather than being inflexibly rooted in perceived notions of expertise, fixed ideologies, or patriarchal constructions of gender.

\section{Contribution}

We see our contribution adding value in four particular ways:

- The blurring of the researcher or participant boundary means that we consider our participants as co-constructers of knowledge. They have cultural capital that is of equal value as the knowledge of the researchers. Their cultural capital often provides us as researchers with new insights into empirical cases. Lisa's critical reflection highlighted her awareness of the complex effects of intersectionality for leaders constructing their identity within traditional management settings. It made her aware of the vulnerability and tensions women leaders experience in establishing their authentic identities in settings which are often hostile and inhibiting. Reflecting on the effects of the duoethnographic methodology on her own researcher identity raised the need for safer spaces to be created in organisations for women and men leaders to share their vulnerabilities and experiences in constructing their leader identities.

- It reframes the idea of collaboration between researchers themselves. Collaboration in management studies is generally understood as co-authoring peer-reviewed articles. Author order becomes the shorthand for the nature of the collaboration (Schultz, 2016). The work tends to be collaborative for instrumental reasons such as achieving publication outputs, sharing of resources and achievement of career goals such as promotion. As Schultz (2016, p. 515) argues, mainstream forms of collaboration assume predetermined research questions, methods and methodology, even before you meet or approach collaborators. There is no room for what may be seen as 'messiness'. By 'messiness', we mean the moments of reflection, disagreement, vulnerability and failure we encounter among ourselves when we collaborate as researchers. Duoethnographic approaches offer a way to organise and publish this 'messiness' through focussed conversation between researchers. The 'lived relationship' between the researchers becomes the collaboration (Schultz, 2016, p. 515; Snipes \& LePeau, 2017). It is valuable to curate this lived relationship because it provides insights into how researcher identity influences knowledge production in a particular discipline. Researchers who have engaged in critical reflection on race and gender, for example, will be more attuned to these identities in their participants (treating these identities as more than variables to be correlated).
They will also be more conscious of how their own identities may influence the way they frame research questions and processes. As Snipes and Lepaeu (2017, p. 580) show, such reflexivity can encourage social justice advocacy (as also encouraged by a CMS approach) because it promotes the 'critical inclusion of multivoiced perspectives'. Without this multivoiced perspective, management studies run the risk of establishing male, capitalist, heterosexual, white, Anglo-Saxon, positivist and western perspectives as universal.

- Duoethnography provides a way to engage with transformative learning for both experienced and less experienced scholars. As a focussed form of dialogical inquiry, it can democratise learning partnerships beyond the mentor-mentee relationship. This takes place by acknowledging equally the cultural and social capital that both the experienced scholar and less experienced scholar bring to the partnership. Ultimately, these contributions can serve as a means of enriching and expanding the scope of the discipline.

- Implications for practice: As with any research design, duoethnography has its limitations. By its nature, duoethnography is a deeply subjective approach. As a form of intersecting autoethnographies, it becomes difficult to apply traditional forms of rigour to assess the 'validity' of the account. It has been described as a process of 'wandering in the woods without a compass' (Breault, 2016, p. 2). Yet, the rapidly emerging scholarship using the approach is resulting in criteria development for good versus bad approaches to duoethnography (2016). We thus suggest that as more scholars use the approach in a South African context, limitations and strategies to mitigate these can be developed over time. As more South African scholars engage with the approach, a set of 'validity' criteria in local settings may emerge.

\section{Acknowledgements Competing interests}

The authors declare that they have no financial or personal relationships that may have inappropriately influenced them in writing this article.

\section{Authors' contributions}

L.K. conducted the PhD study on which the autoethnographic reflection is based. The article is her autoethnographic account and reflection on the positioning of researcher identity and purpose in management research. S.R. shaped the introduction and theoretical frameworks that guided the research and located it within the broader context. S.R. advised on the methodology and findings and reviewed and edited these sections of the article.

\section{Funding information}

This research received no specific grant from any funding agency in the public, commercial, or not-for-profit sectors. 


\section{Data availability statement}

Data sharing is not applicable to this article as no new data were created or analysed in this study.

\section{Disclaimer}

The views expressed in this article are the authors' own and do not reflect the views of their institutions, employers or funders.

\section{References}

Alvesson, M., \& Ashcraft, K. L. (2009). Critical methodology in management and organization research. In A. Bryman \& D. Buchanan (Ed.), The SAGE handbook of organizational research methods (pp. 61-77). London: SAGE.

Alvesson, M., Bridgman, T., \& Willmott, H. (2011). Handbook of critical management studies. Oxford: Oxford University Press.

Anderson, L. (2006). Analytic autoethnography. Journal of Contemporary Ethnography, 35(4), 373-395. https://doi.org/10.1177/0891241605280449

Bell, E., \& King, D. (2010). The elephant in the room: Critical management studies conferences as a site of body pedagogics. Management Learning, 41(4), 429-442. https://doi.org/10.1177/1350507609348851

Beltramini, E. (2018). Philosophy of management between scientism and technology. Philosophy \& Technology, 1, 1-14. https://doi.org/10.1007/s13347 018-0314-6

Bratton, J., \& Gold, J. (2015). Towards critical human resource management education (CHRME): A sociological imagination approach. Work, Employment and Society, 29(3), 496-507. https://doi.org/10.1177/0950017014545266

Breault, R. (2016). Emerging issues in duoethnography. International Journal of Qualitative Studies in Education, 29(6), 777-794.

Carrim, N. M. H., \& Nkomo, S. M. (2016). Wedding intersectionality theory and identity work in organisations: South African Indian women negotiating managerial work in organisations: South African Indian women negotiating managerial
identity. Gender, Work and Organization, 23(3), 261-277. https://doi.org/10.1111/ gwao.12121

Chang, H. (2007). Autoethnography: Raising cultural consciousness of self and others In G. Walford (Ed.), Methodological developments in ethnography: Studies in educational ethnography, vol. 12, pp. 207-221. Boston, MA: Elsevier.

Crenshaw, K. (1991). Mapping the margins: Intersectionality, identity politics, and violence against women of colour. Stanford Law Review, 43(6), 1241-1299. https://doi.org/10.2307/1229039

Davis, K. (2008). Intersectionality as buzzword: A sociology of science perspective on what makes a feminist theory successful. Feminist Theory, 9(1), 67-85. https:// doi.org/10.1177/1464700108086364

Doloriert, C., \& Sambrook, S. (2012). Organisational autoethnography. Journal of Organizational Ethnography, 1(1), 83-95. https://doi.org/10.1108/2046674 1211220688

Dunbar, R. L., \& Rottner, R. (2014). The power of Babel: Thinking through academic management's institutionalised conversation. Academy of Management Proceedings, 2014(1), 1583-1588. https://doi.org/10.5465/ambpp.2014.150

Ellis, C., Adams, T. E., \& Bochner, A. P. (2011). Autoethnography: An overview. Forum Qualitative Sozialforschung/Forum: Qualitative Social Research, 12(1), Art 10 https://doi.org/10.17169/fqs-12.1.1589

Fitzpatrick, E., \& Farquhar, S. (2018). Service and leadership in the university: Duoethnography as transformation. Journal of Organizational Ethnography, $7(3)$ 345-360. https://doi.org/10.1108/JOE-08-2017-0037

Fleming, P., \& Spicer, A. (2014). Power in management and organisation. The Academy of Management Annals, 8(1), 237-298.

Ford, J., \& Harding, N. (2010). Get back into that kitchen, woman: Management conferences and the making of the female professional worker. Gender, Work\&Organization, 17(5),503-520. https://doi.org/10.1111/j.1468-0432.2009. 00476.x

Goldman, G. A. (2016). On the possibility of fostering critical management studies in South Africa. In G. A. Goldman (Ed.), Critical management studies in the South African context (pp. 3-29). Durbanville, Cape Town: AOSIS (Pty) Ltd.

Gouws, A. (2012). Reflections on being a feminist academic/academic feminism in South Africa. Equality, Diversity and Inclusion: An International Journal, 31(5-6), $526-541$.

Guyotte, K. W., \& Sochacka, N. W. (2016). Is this research? Productive tensions in living the (collaborative) autoethnographic process. International Journal of Qualitative Methods, 15(1), 1-11. https://doi.org/10.1177/1609406916631758

Harvey, J. (2010). Victims, resistance, and civilised oppression. Journal of Socia Philosophy, 41(1), 13-27. https://doi.org/10.1111/j.1467-9833.2009.01475.x

Hibbert, P., \& Cunliffe, A. (2015). Responsible management: Engaging moral reflexive practice through threshold concepts. Journal of Business Ethics, 127, 177-188. https://doi.org/10.1007/s10551-013-1993-7

Hooks, B. (1994). Outlaw Cultures: Resisting representations. New York and London: Routledge.
Hooks, B. (2010). Teaching critical thinking: Practical wisdom. New York: Routledge.

Huzzard, T., \& Johansson, Y. (2014). Critical action research. In E. Jeanes \& T. Huzzard (Eds.), Critical management research: Reflections from the field (pp. 81-101). London: SAGE.

Kinnear, L., \& Ortlepp, K. (2016). Emerging models of power among South African women business leaders. SA Journal of Industrial Psychology, 42, 1-12. https:// doi.org/10.4102/sajip.v42i1.1359

Le Roux, A. (2014). 'We were not part of apartheid': Rationalisations used by four white pre-service teachers to make sense of race and their own racial identities. South African Journal of Education, 34(2), 1-16. https://doi.org/10.15700/ 201412071137

Letherby, G. (2003). Feminist research in theory and practice. Buckingham: Open University Press.

Lykke, N., Brewster, A., Davis, K., Koobak, R., Lie, S., \& Petö, A. (2014). Editoria Introduction. In N. Lykke (Ed.), Writing academic texts differently: Intersectional feminist methodologies and the playful art of writing (pp. 1-13). New York, NY: Routledge.

Mall, F. (2015). Preface: The importance of gender inclusivity. In Business Women's Association of South Africa (Ed.), Business women's association of South Africa, BWASA South African Women in Leadership Census 2015 (pp. 6-9). Parktown, Johannesburg: Business Women's Association of South Africa.

Meier, C., \& Geldenhuys, D. J. (2017). Co-constructing Appreciative Inquiry across disciplines: A duo-ethnography. SA Journal of Industrial Psychology, 43(1), 1-9. https://doi.org/10.4102/sajip.v43i0.1400

Milazzo, M. (2015). The rhetorics of racial power: Enforcing colour blindness in post-apartheid scholarship on race. Journal of International and Intercultura Communication, 8(1), 7-26. https://doi.org/10.1080/17513057.2015.991075

Miller, D. (2016). Excavating the vernacular: 'Ugly feminists', generational blues and matriarchal leadership. In S. Booysen, (Ed.), Fees must fall: Student revolt, decolonisation and governance in South Africa (pp. 270-291). Johannesburg: Wits University Press.

Morrell, R., Jewkes, R., \& Lindegger, G. (2012). Hegemonic masculinity/masculinities in South Africa: Culture, power, and gender politics. Men and Masculinities, 15(1) 11-30. https://doi.org/10.1177/1097184X12438001

Nkomo, S. (2018). Reflections on Africapitalism and management education in Africa. In K. Amaeshi, A. Okupe, \& U. Idemudia (Eds.), Africapitalism: Rethinking the role of business in Africa (pp. 261-281). Cambridge: Cambridge University the role
Press.

Nkomo, S. M. (2011). A postcolonial and anti-colonial reading of 'African' leadership and management in organisation studies: Tensions, contradictions and possibilities. Organization, 18(3), 365-386. https://doi.org/10.1177/1350508411398731

Norris, J. (2008). Duoethnography. The SAGE encyclopedia of qualitative research methods (vol. 1, pp. 233-236). Los Angeles, CA: SAGE.

Norris, J., \& Sawyer, R. D. (2012). Toward a dialogic methodology. In J. Norris, R. D. Sawyer, \& D. E. Lund (Eds.), Duoethnography: Dialogic methods for social, health, and educational research (pp. 9-39). Walnut Creek, CA: Left Coast Social,
Press.

Norris, J., \& Sawyer, R. (2016). Interdisciplinary reflective practice through duoethnography: Examples for educators. New York: Springer.

O'Neil, S., \& Koekemoer, E. (2016). Two decades of qualitative research in psychology, industrial psychology and human resource management within South Africa: A critical review. SA Journal of Industrial Psychology, 42(1), 279-287. https://doi. A critical review. SA Journal of
org/10.4102/sajip.v42i1.1350

Pietersen, C. (2018). Research trends in the South African Journal of Human Resource Management. SA Journal of Human Resource Management, 16(1), 1-9. https:// doi.org/10.4102/sajhrm.v16i0.825

Ponterotto, J. G. (2013). Case study in psychobiographical ethics: Bobby Fischer, world chess champion. Journal of Empirical Research on Human Research Ethics, 8(4), 19-27. https://doi.org/10.1525/jer.2013.8.4.19

Prinsloo, E. H. (2016). The role of the humanities in decolonising the academy. Arts and Humanities in Higher Education, 15(1), 164-168. https://doi.org/10.1177/ 1474022215613608

Ruel, S., Mills, A. J., \& Thomas, J. L. (2015). A 'fiery, fighter, bitchy' 'Harlem Princess': An archaeo-genealogical enquiry into intersectionality. Academy of Management Annual Meeting Proceedings, 2015(1), 12898. https://doi.org/10.5465/ambpp. 2015.12898abstract

Ruggunan, S. (2016). Decolonising management studies: A love story. In G. A. Goldman (Ed.), Critical management studies in the South African context (pp. 103-137). Durbanville, Cape Town: AOSIS (Pty) Ltd.

Ruggunan, S., \& Sooryamoorthy, R. (2016). Human resource management research in South Africa: A bibliometric study of features and trends. Journal of Contemporary Management, 13, 1-34.

Sawyer, R., \& Norris, J. (2005). Towards the dialogic and critical engagement of duoethnography for transformative curriculum: An interactive discussion of methodology. Paper presented at the Curriculum and Pedagogy conference, 7-12th November, Oxford University Press, Akron, $\mathrm{OH}$.

Sawyer, R., \& Norris, J. (2015). Duoethnography. International Review of Qualitative Research, 8(1), 1-4. https://doi.org/10.1525/irqr.2015.8.1.1

Schultz, C. S. (2017). 'Working the ruins' of collaborative feminist research. International Journal of Qualitative Studies in Education, 30(6), 505-518. https://doi.org/10. 1080/09518398.2016.1250175 
Smith, C. (2005). Epistemological intimacy: A move to autoethnography. International Journal of Qualitative Methods, 4(2), 68-76. https://doi.org/10.1177/160940690 500400206

Snipes, J. T., \& LePeau, L. A. (2017). Becoming a scholar: A duoethnography of transformative learning spaces. International Journal of Qualitative Studies in Education, 30(6), 576-595. https://doi.org/10.1080/09518398.2016.1269972

Swartz, S., Arogundade, E., \& Davis, D. (2014). Unpacking (white) privilege in a South African university classroom: A neglected element in multicultural educational contexts. Journal of Moral Education, 43(3), 345-361. https://doi.org/10.1080/03 057240.2014 .922942
Van Schalkwyk, S., \& McMillan, W. J. (2016). 'I have a chameleon-like existence': A duoethnographic account of border crossing by two academic development practitioners. South African Journal of Higher Education, 30(6), 207-223. https:// doi.org/10.20853/30-6-735

Wall, S. (2006). An autoethnography on learning about autoethnography. Internationa Journal of Qualitative Methods, 5(2), 1-12. https://doi.org/10.1177/160940690 600500205

Zanoni, P., Janssens, M., Benschop, Y., \& Nkomo, S. (2010). Guest editorial: Unpacking diversity, grasping inequality: Rethinking difference through critical perspectives. Organization, 17(1), 9-29. https://doi.org/10.1177/1350508409350344 